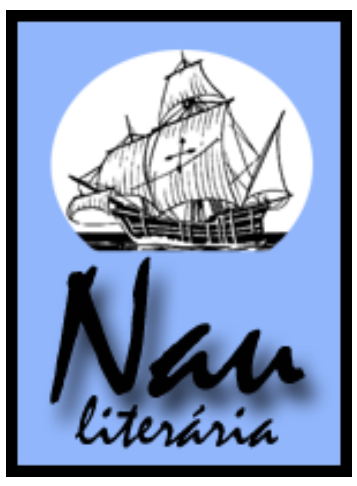

Nau Literária: crítica e teoria de literaturas • seer.ufrgs.br/NauLiteraria
ISSN 1981-4526・PPG-LET-UFRGS • Porto Alegre • Vol. 10 N. $02 \bullet$ jul/dez 2014
Dossiê: Migração, exílio e identidade

\title{
A violência divina denunciada nos romances de José Saramago
}

Maiquel Röhrig ${ }^{1}$

\begin{abstract}
Resumo: Neste artigo, analiso os romances $O$ evangelho segundo Jesus Cristo e Caim, de José Saramago, confrontando seus principais episódios com aqueles narrados pela Bíblia e com o debate histórico sobre sua ocorrência. O objetivo é discutir as violências atribuídas ao personagem Deus à luz do conceito de paródia, revelando o modo como Saramago se apropria do texto bíblico. Além disso, procuro inserir a discussão no âmbito da história e da arqueologia, a fim de pontuar o que se chama de "heresias" de Saramago num contexto diferente do discurso teológico, comparando as violências praticadas por Deus nas obras de Saramago com aquelas narradas nos textos da Bíblia.
\end{abstract}

Palavras-chave: paródia; Antigo Testamento; Saramago; Caim; O evangelho segundo Jesus Cristo.

\begin{abstract}
This article discusses the novels The gospel according to Jesus Christ and Cain by Jose Saramago, confronting its main episodes with those narrated by the Bible and the historical debate about its occurrence. The goal is to discuss the violence attributed to God's character in light of the concept of parody, revealing how Saramago appropriates the biblical text. Also, try to put the discussion on the history and archeology in order to punctuate what is called the "heresies" of Saramago, comparing the violence perpetrated by God in Saramago's works with those narrated in the texts of the Bible.
\end{abstract}

Keywords: parody; Old Testament; Saramago; Cain; The gospel according to Jesus Christ.

\section{Teoria da paródia}

Os romances $O$ evangelho segundo Jesus Cristo e Caim apresentam a paródia como tema central de suas narrativas. Por isso, muitos leitores os consideram heresias que apresentam Deus de modo pejorativo, através de desvios, deslocamentos e exageros, portanto não correspondendo ao Deus da Bíblia. Logo, compreendem essas paródias como se fossem ridicularizações do original. No caso do Evangelho, Saramago cria cenas e modifica outras constantes no Novo Testamento. Em Caim, o autor concentra-se em eventos presentes no Antigo Testamento, modificando-os apenas no tocante à presença de caim ${ }^{2}$, que assiste a tudo. No entanto, para compreendermos esses romances naquilo que eles têm de literário e ideológico, é preciso entender o que é, modernamente, a paródia.

O conceito de paródia modificou-se muito ao longo do tempo, e a própria palavra contém elementos com sentido controverso ${ }^{3}$. Com a popularização das paródias musicais, formou-se a ideia de que a paródia é uma técnica humorística e ridicularizadora. No entanto, escritores têm se valido dela para compor textos de outra natureza, não voltados para a deturpação cômica do texto original.

\footnotetext{
${ }^{1}$ Doutor em Literatura Comparada pela UFRGS (Universidade Federal do Rio Grande do Sul).

${ }^{2}$ Este romance apresenta os nomes próprios grafados com letra inicial minúscula. Mantive essa forma quando me referi aos seus personagens.

${ }^{3}$ Os significados do prefixo para são vários, e, somados ao radical odia, podem gerar: 1) cantar ao lado (deslocamento);

2) cantar conforme (imitação); 2) cantar a mais (adição); 3) cantar contra (oposição).
} 
A paródia não se dirige diretamente ao real, mas, como explica Moser (1992 p.134), “a formas de representação que, tendo se tornado doutrinárias ou estratificadas, não correspondem mais nem ao real nem aos conteúdos da consciência humana e têm, conseqüentemente, um efeito alienante" . Ela pode afetar um modelo completo ou apenas certas partes de um dado modelo. Uma vez que sua referência são outros textos, e não diretamente o real, categorias como a verossimilhança não se aplicam à paródia.

A teoria da paródia de Linda Hutcheon abarca a maneira como Saramago se vale das narrativas bíblicas. Segundo ela,

quando falo em "paródia", não estou me referindo à imitação ridicularizadora das teorias e das definições padronizadas que se originam das teorias de humor do século XVIII. A importância coletiva da prática paródica sugere uma redefinição da paródia como uma repetição com distância crítica que permite a indicação irônica da diferença no próprio âmago da semelhança. [...] essa paródia realiza paradoxalmente tanto a mudança como a continuidade cultural: o prefixo grego para- pode tanto significar "contra" como "perto" ou "ao lado" (1991, p. 47, grifos da autora).

A mesma autora, na obra em que se dedica exclusivamente à teoria da paródia $(1989$, p. 54), reafirma essa ideia: “A paródia é repetição, mas repetição que inclui diferença; é imitação com distância crítica, cuja ironia pode beneficiar e prejudicar ao mesmo tempo".

Saramago não ridiculariza os textos bíblicos. O autor reproduz as histórias da Bíblia, repeteas e cria o efeito de estranhamento justamente através da apresentação de Deus tal como ele aparece na maioria das vezes em que é mencionado no Antigo Testamento.

A paródia de Saramago inclui a paráfrase, isto é, utiliza, ipsis litteris, trechos do texto original. O inusitado em seus textos é que suas paráfrases dão a impressão de que são desvios, quando são elas que, em relação ao texto bíblico, são fiéis. O desvio que a paródia de Saramago empreende é em relação à imagem de Deus como personagem sempre piedoso e bom, o que é desmentido pelos textos da Bíblia.

Moser não pensa a paródia somente como intertextualidade. Ampliando, e de certo modo opondo-se ao que pensa Hutcheon, ele afirma que se deve analisar também a paródia de estilo e a paródia de discursos. Nessa última, segundo ele (1992, p. 140), o autor não se refere a um texto específico, mas a "uma fórmula gerativa de textos: por exemplo, um certo discurso científico, administrativo, etc.”. N'O evangelho segundo Jesus Cristo, o título prepara a paródia do gênero, ou estilo, "evangelho", mas isso não se confirma, pois, além de se tratar de um romance, é um romance segundo um narrador, porque não é Jesus quem conta sua história. Também se vê pouco a figura de

\footnotetext{
${ }^{4}$ Esta definição aplica-se bem às paródias de Saramago, uma vez que a doutrina cristã impõe uma interpretação da Bíblia que aliena as pessoas do texto. Os padres, por exemplo, há apenas menos de um século abandonaram o latim para finalmente rezarem missa no idioma do povo para o qual pregam. A primeira tradução da Bíblia é do século XVI, e só foi possível graças à Reforma de Martinho Lutero.
} 
Nau Literária • ISSN 1981-4526 • VOL. 10, N. 02 • JUL/DEZ 2014 • seer.uffrgs.br/NauLiteraria

Cristo, uma vez que no Evangelho de Saramago o narrador concentra-se na humanidade de Jesus, quase se apagando a imagem divina do Cristo.

A paródia não é apenas um procedimento adotado nos romances de Saramago, é, sobretudo, um núcleo a partir do qual se criam os efeitos estéticos das obras. Essas paródias de Saramago, ao mesmo tempo que dialogam intertextualmente com a Bíblia, alimentam-se dos questionamentos emprendidos por historiadores e arqueólogos. O autor recria cenários e compõe suas personagens mesclando as descrições bíblicas às evidências arqueológicas e à problematização do contexto histórico em que as narrativas se inserem ${ }^{5}$.

\section{As paródias de Saramago}

O evangelho segundo Jesus Cristo, publicado em 1991, tem 24 capítulos, não numerados, que totalizam 445 páginas. É o romance mais longo de Saramago. O texto conta a história de Jesus desde sua concepção até sua crucificação. O autor recria a vida de Jesus a partir do Novo Testamento, porém humaniza a personagem, subvertendo alguns eventos que, na Bíblia, divinizamno. Saramago recorre à paródia, mas também à historiografia, para compor sua narrativa.

O Demônio está presente na vida de Jesus desde sua concepção até momentos antes de sua morte. Durante quatro anos, atendendo pelo nome de Pastor, acolhe Jesus ensinando-lhe o ofício de pastorear ovelhas. Mais do que isso, tenta ensinar seu pupilo a enxergar a vida sem a alienação da lei judaica, mostrando-lhe as incoerências e crueldades de Deus. Jesus, no entanto, não aprende. Quando encontra Deus no deserto e sacrifica-lhe uma ovelha, Pastor o expulsa ${ }^{6}$.

Deus é, por sua vez, o grande antagonista da obra, porque, enquanto Jesus e o Demônio buscam amar e compreender os homens, Deus trabalha para submetê-los a sua vontade, ampliar o número de seus fiéis e o poder que tem sobre eles.

O Diabo tentou evitar que o sacrifício de Jesus acontecesse. Esteve presente em momentos decisivos de sua vida, desde sua concepção e, por quatro anos, procurou ensiná-lo a amar a vida, mostrando-lhe que às vezes isso significaria opor-se aos ritos judaicos. Porém, Jesus não aprendeu tudo. O Diabo esforçou-se para salvar a raça humana e o próprio Jesus, mas este não foi um bom discípulo e, por isso, condenou a humanidade a cultuar um deus sanguinário.

A lista de atrocidades e de mortos relacionados ao cristianismo é extensa. Inquirido insistentemente por Jesus, Deus enumera pessoas mortas em seu nome ${ }^{7}$. E Jesus compreende:

\footnotetext{
${ }^{5}$ A dimensão histórica do Evangelho não se refere à autenticidade das histórias sobre Jesus, e sim da recriação do ambiente, da política e da cultura em que viviam homens e mulheres da região onde Jesus teria nascido.

${ }^{6}$ Neste Evangelho, as tentações de Jesus são sempre obras de Deus, enquanto o Demônio procura ensinar-lhe o amor aos homens.

7 O “dicionário de mortes" vai da p. 381 à p. 385.
} 
Morrerão centenas de milhares de homens e mulheres, a terra encher-se-á de gritos de dor, de uivos e roncos de agonia, o fumo dos queimados cobrirá o sol, a gordura deles rechinará sobre as brasas, o cheiro agoniará, e tudo isto será por minha culpa, Não por tua culpa, por tua causa, Pai, afasta de mim este cálice ${ }^{8}$, Que tu o bebas é a condição do meu poder e da tua glória, Não quero esta glória, Mas eu quero esse poder. [...] Então o Diabo disse, É preciso ser-se Deus para gostar tanto de sangue (p. 391).

Deus estava insatisfeito pois o povo que lhe adorava era pequeno. Ele queria ampliar seus domínios $^{9}$ e, para isso, precisava que Jesus morresse como vítima. Deus explica a Jesus como será sua morte: “A um mártir convém-lhe uma morte dolorosa, e se possível infame, para que a atitude dos crentes se torne mais facilmente sensível, apaixonada, emotiva, Não esteja de rodeios, diz-me que morte será a minha, Dolorosa, infame, na cruz" (p. 371).

O papel destinado a Jesus no plano de Deus, segundo o próprio Deus, é "O de mártir, meu filho, o de vítima, que é o que de melhor há para fazer espalhar uma crença e afervorar uma fé” (p. 370). Antes, Deus explica que Jesus deveria fazer milagres e contar histórias ao povo, "parábolas, exemplos morais, mesmo que tenhas de torcer um bocadinho a lei, não te importes” (p. 376). Jesus retruca: "Permites que te subvertam as leis ${ }^{10}$, é um mal sinal, Permito-o quando me serve, e chego a querê-lo quando me é útil, [...] o que a minha vontade quer torna-se obrigatório no mesmo instante" (p. 377).

Jesus luta com todas as suas forças para não realizar o plano de Deus, mas é impossível. Conforme Souza (s/d, p. 7), Deus se mostra "pouco interessado pelos assuntos humanos: o que ele deseja é sua auto-satisfação". Assim, Saramago inverte a imagem do salvador, transformando-o no responsável involuntário por nossa perdição.

Caim é, curiosamente, ao contrário do Evangelho, o romance mais curto de Saramago, e o único em que os capítulos são numerados e em que os personagens e nomes de cidades são grafados com letra inicial minúscula. Nenhum substantivo recebe o tratamento especial da maiúscula, inclusive deus ${ }^{11}$. Com isso, o autor elimina a supremacia dos nomes próprios em relação às outras palavras, deixando em igualdade todas as palavras do texto.

O romance aborda diversos eventos narrados no Antigo Testamento. Começa pela criação e pelo jardin do Éden, e termina no dilúvio universal e na arca de Noé. A única referência ao Novo Testamento é a epígrafe, extraída de Hebreus, 11, 4. Nela, Saramago mantém as iniciais maiúsculas dos nomes das personagens: "Pela fé, Abel ofereceu a Deus um sacrifício melhor do que o de Caim. Por causa da sua fé, Deus considerou-o seu amigo e aceitou com agrado as suas ofertas. E é pela fé que Abel, embora tenha morrido, ainda fala”. O romance irá contradizer essa epígrafe e explicará o

\footnotetext{
${ }^{8}$ Em Mt 26, 39, em Mc 14, 36 e em Lc 22, 42, o cálice refere-se à morte do próprio Cristo. Aqui, Jesus usa o cálice como metáfora das outras milhares de vidas que morrerão por sua culpa, ou por sua causa.

${ }^{9} \mathrm{E}$, se aumentam os poderes de Deus, também aumentam os do Diabo, por isso ele também está na barca.

${ }^{10}$ Ferraz (s/d, p. 11) afirma que Deus "permite que ela [a lei] seja subvertida quando é interessante para os seus propósitos malignos".

${ }^{11}$ Vou utilizar essa mesma convenção ao me referir às personagens deste romance. Quando me referir ao homônimo da Bíblia, usarei maiúscula. Os nomes de cidades, contudo, escreverei sempre com inicial maiúscula.
} 
fato de o autor tê-la atribuído ao "LIVRO DOS DISPARATES", escrito ironicamente assim mesmo, com todas as letras em maiúsculas. É um disparate pois, segundo o romance, não foi a falta de fé que condenou caim, mas a crueldade de deus, que rejeitou o sacrifício dos vegetais que caim lhe oferecia, não porque o sacrifício era pior, mas porque para deus o sacrifício deve ter sangue.

Caim mata abel após uma semana em que a cena dos sacrifícios se repete diariamente: o de abel, aceito sempre, o de caim, sempre rejeitado. E todas as vezes, "sempre a falta de piedade de abel, os dichotes de abel, o desprezo de abel" (p. 33). Caim premedita a morte do irmão, chama-o para um passeio. Quando chegam ao local onde escondera uma queixada de jumento, usa-a para golpeá-lo até a morte. Neste momento, ao invés de mandar um anjo, como faz posteriormente no caso da prova à que submete abraão, deus aparece, em pessoa, dizendo que o pusera à prova. Esta aparição, paráfrase do texto bíblico ${ }^{12}$, o narrador anuncia acrescentando um comentário: "Foi nesse exacto momento, isto é, atrasada em relação aos acontecimentos ${ }^{13}$, que a voz do senhor soou, e não só soou ela como apareceu ele" (p. 34). Na sequência, os dois dialogam:

\begin{abstract}
Mataste-o, Assim é, mas o primeiro culpado és tu, eu daria a minha vida pela vida dele se tu não tivesses destruído a minha, Quis pôr-te à prova, E tu quem és para pores à prova o que tu mesmo criaste, Sou o dono soberano de todas as coisas, E de todos os seres, dirás, mas não de mim nem da minha liberdade, Liberdade para matar, Como tu foste livre para deixar que eu matasse a abel quando estava na tua mão evitá-lo, bastaria que por um momento abandonasses a soberba da infalibilidade que partilhas com todos os outros deuses, bastaria que por um momento fosses realmente misericordioso, que aceitasses a minha oferenda com humildade, só porque não deverias atrever-te a recusá-la, os deuses, e tu como os outros, têm deveres para com aqueles a quem dizem ter criado (p. 34).
\end{abstract}

Caim arremata: "matei abel porque não podia matar-te a ti, pela intenção estás morto" (p. 35). Diante dos argumentos de caim, deus titubeia e decide negociar. Amaldiçoa-o a andar errante pelo mundo, mas põe-lhe um sinal na testa que o protegerá de ser assassinado: "Diremos que é um acordo de responsabilidade partilhada pela morte de abel, Reconheces então a tua parte de culpa, Reconheço, mas não o digas a ninguém, será um segredo entre deus e caim” (p. 35) ${ }^{14}$.

A maldição no romance não se limita ao espaço, incidindo também sobre o tempo. Isso ocorre para que caim possa presenciar episódios narrados na Bíblia separados por séculos ${ }^{15}$, como o quase sacrifício de isaac, a construção da torre de babel, a história de moisés no monte sinai, as desventuras de job, a batalha de jericó, a arca de noé etc. Saramago cria uma espécie de "portais no tempo", de modo que caim, da mesma forma que se move no espaço, passe de um tempo ao outro à medida que caminha errante pelo mundo ${ }^{16}$.

\footnotetext{
$12 \mathrm{Gn} \mathrm{4,9.}$

${ }^{13}$ No caso de abraão e seu filho isaac, o anjo do senhor também se atrasa. Isaac não foi morto graças a caim.

${ }^{14} \mathrm{Na}$ Bíblia, Caim também negocia com Deus, mas não o culpa pela morte de Abel, como fez o personagem de Saramago (Gn, 4, 8-17).

${ }^{15}$ Mesmo considerando que os primeiros humanos, segundo a Bíblia, viviam por séculos, caim não poderia viver tempo o bastante para presenciar todos estes episódios, uma vez que eles estão separados por um tempo maior do que o tempo de vida de Matusalém, o homem que viveu por mais tempo na narrativa bíblica: 969 anos.

${ }^{16}$ O evangelho segundo Jesus Cristo contém uma subversão do tempo na cena da barca, que, para Jesus, durou o tempo
} 
Nau Literária • ISSN 1981-4526 • VOL. 10, N. 02 • JUL/DEZ 2014 • seer.uffrgs.br/NauLiteraria

Ao parodiar os textos bíblicos, Saramago polemizou com religiosos e leitores, e estimulou debates entre críticos e pesquisadores da literatura. Há quem leia seus romances sob um viés puramente religioso, ignorando seu caráter literário. A incompreensão da obra enquanto literatura e a leitura puramente religiosa do texto resultaram num fato famoso: a retirada do Evangelho de um concurso em Portugal, o que irritou Saramago a ponto de ele sair do país e exilar-se numa das ilhas Canárias.

Caim é um romance paródico em que predomina a repetição com distanciamento crítico: o texto original é inserido num contexto em que sua autoridade é questionada e as atrocidades narradas são denunciadas. O Evangelho segundo Jesus Cristo é construído a partir de deslocamentos e invenções criadas para compor de modo coerente a história de Jesus e de sua família, bem como para humanizar a figura de Jesus, respeitar o contexto histórico, criticar Deus e enaltecer o Demônio.

\section{0 diálogo com a história e a arqueologia}

Escavações encontraram, nos dois últimos séculos, evidências e vestígios ligados à ocorrência histórica, ou à não ocorrência, dos relatos da Bíblia. Porém, os pesquisadores interpretam os achados arqueológicos de modos diferentes. A maioria tem uma postura crítica frente aos textos bíblicos (por exemplo, Mario Liverani, Finkelstein \& Silberman), mas há aqueles que encaram as descobertas arqueológicas segundo sua fé, e as analisam de modo a confirmá-la (como Paul Johnson). Da mesma forma, muitos leitores e críticos de literatura leem a obra de Saramago com uma "aversão cristã", imputando a suas histórias a alcunha de heresias.

Confronto alguns dos episódios bíblicos utilizados por José Saramago com o relato da Bíblia. Outros, confronto também com textos de historiadores e arqueólogos, a fim de registrar a polêmica que os envolve e situar os romances nesse contexto de questionamento da verdade que a Bíblia supostamente representa, de modo a destacar que não se trata apenas de uma discussão literária e religiosa, mas, também, histórica.

Julgo importante frisar que os esforços dos arqueólogos e historiadores ocorre porque os eventos apontados não são considerados pelos judeus como simbólicos, e sim, históricos, assim como a vida de Jesus, seus milagres e ressurreição são considerados fatos históricos para os católicos.

A crueldade de Deus com as mulheres, condenadas a sofrerem as dores do parto como penitência ao pecado de Eva, aparece nos dois romances paródicos de Saramago. No Evangelho, a parteira que ampara a mãe de Jesus pensa que “o padecimento desta pobre mulher é igual ao de

de uma conversa e, para os que ficaram em terra, demorou quarenta dias. Em Caim, as subversões temporais são muito maiores. 
todas as outras mulheres, como foi determinado pelo Senhor Deus quando Eva errou por desobediência". Depois, o narrador cita Gn 3, 16: “Aumentarei os sofrimentos da tua gravidez, os teus filhos nascerão entre dores", e comenta que "hoje, passados já tantos séculos, com tanta dor acumulada, Deus ainda não se dá por satisfeito e a agonia continua” (p. 82-83). Em Caim, a mesma frase do Gênesis é parafraseada em meio à maldição que deus lança a adão e eva por terem comido um fruto da árvore do conhecimento do bem e do mal, agora não apenas para mostrar a crueldade contra a mulher, mas a vingança contra ela e contra o homem:

já que assim o quiseram, assim o vão ter, a partir de agora acabou-se-lhes a boa vida, tu, eva, não só
sofrerás todos os incómodos da gravidez, incluindo os enjoos, como parirás com dores, e não obstante
sentirás atracção pelo teu homem, e ele mandará em ti, Pobre eva, começas mal, triste destino vai ser o
teu, disse eva, Devias tê-lo pensado antes, e quanto à tua pessoa, adão, a terra ficou amaldiçoada por
tua causa, e será com grande sacrifício que dela conseguirás tirar alimento durante toda a tua vida, só
produzirá espinhos e cardos, e tu terás de comer a erva que cresce no campo, só à custa de muitas
bagas de suor conseguirás arranjar o necessário para comer, até que um dia te venhas a transformar de
novo em terra, pois dela foste formado, na verdade, mísero adão, tu és pó e ao pó um dia tornarás (17-
$18)^{17}$.

Liverani explica que o Jardim do Éden tem um correspondente histórico, ou, pelo menos, é possível verificar que houve uma referência real a partir da qual os judeus criaram essa história. Segundo Liverani,

Em meio à paisagem desolada e selvagem, constituíam-se também núcleos de ordem e de produtividade. Eram fazendas agrícolas em que a zona hortícola (com tamareiras, árvores frutíferas e culturas de cebolas, alface, legumes) era cuidadosamente servida por canais de irrigação, intensamente atendida pelo trabalho dos encarregados e toda cercada para proteção contra furtos e estragos por homens e animais. Mas essas normais unidades produtivas encontravam seu modelo e sua sublimação, mais de caráter supérfluo e de ostentação, no jardim régio, que concentrava árvores e plantas ornamentais e animais e aves. Esses jardins régios constituíam o modelo do "jardim do Éden”, onde está ambientada a histórica bíblica de Adão e Eva (2008, p. 295).

O autor continua explicando a configuração da história: um jardim maravilhoso que se opõe à dureza da vida fora dele:

O paraíso, porém, é também símbolo de uma condição existencial marcada por sentimentos contrapostos de inclusão/exclusão, de proteção/exposição, de facilidade/dificuldade. Dentro do paraíso tudo é fácil e espontâneo: as águas de irrigação, as árvores frutíferas, os próprios habitantes, que vivem em repouso e inocência. Fora, tudo se torna difícil e cansativo: o espaço aberto se torna produtivo somente depois de trabalho extenuante. Mas o acesso ao jardim é proibido ao comum dos mortais, o qual, portanto, deve encetar uma vida de provação para garantir uma problemática sobrevivência (id., p. 296).

E conclui:

A história de Adão e Eva tem, portanto, uma ambientação paisagística babilônia, mas de época persa, e elabora meditações sobre a mortalidade humana que são de claro clichê babilônio. Os redatores da história bíblica devem ter vivido na Babilônia no primeiro período dos aquemênidas (id., p. 297).

\footnotetext{
${ }^{17}$ Esse trecho é uma paráfrase de Gn 3, 16-19.
} 
José sofre com pesadelos durante anos, atormentado pela culpa de ter salvo seu filho e nada ter feito para avisar os outros pais, cujos filhos foram assassinados pelos soldados de Herodes. Saramago utiliza esse expediente para questionar os atos de Deus, e perguntar quando lhe ocorrerá conhecer o sentimento de culpa pelo que considera as maldades que cometeu ou ordenou aos homens que cometessem por ele:

veja-se o caso de José, que tendo Deus, em lugar do anjo, posto no seu caminho um cabo e três soldados faladores, não aproveitou o tempo que tinha para salvar da morte os meninos de Belém. Porém, se os bons começos de Jesus não se perderem na mudança da idade, talvez que ele venha a querer saber por que salvou Deus a Isaac e nada fez para salvar os tristes infantes que, inocentes de pecado como o filho de Abraão, não encontraram piedade perante o trono do Senhor. E, assim sendo, Jesus poderá dizer ao seu progenitor, Pai, não tens de levar contigo toda a culpa, e, no segredo do seu coração, quiçá ouse perguntar, Quando chegará, Senhor, o dia em que virás a nós para conheceres os teus erros perante os homens (p. 144).

Essa última pergunta é retomada no romance Caim, no qual o protagonista se esforça para frustrar os planos de deus. Caim mata noé e sua família, de modo que o repovoamento da terra, pretendido pelo senhor, não aconteça: “Como te atreveste, assassino, a contrariar o meu projecto, é assim que me agradeces ter-te poupado a vida quando mataste abel, perguntou o senhor, Teria de chegar o dia em que alguém te colocaria perante a tua verdadeira face" (p. 172) ${ }^{18}$.

Jesus planeja ser crucificado como rei dos judeus. Com isso, pretende burlar as intenções de Deus, que espera vê-lo crucificado como seu filho, a fim de que sua morte amplie seu poder. Para alcançar seu intento, Jesus precisa de alguém que o denuncie. Os discípulos se negam a isso, mas Judas Iscariotes mostra-se o mais obediente, e se dispõe a ajudar seu mestre. Ao contrário do que dizem os evangelhos, no romance de Saramago, Judas não é o traidor: ele é obediente e solidário, pois ajuda Jesus na realização de seu plano. Depois, "numa figueira à beira do caminho por onde Jesus teria de passar, pendurado pelo pescoço, estava o discípulo que se apresentara voluntário para que pudesse ser cumprida a derradeira vontade do mestre" (p. 438). Os soldados vasculham seus bolsos e nada encontram, pois ele se negara a receber o pagamento pela denúncia (p. 439) ${ }^{19}$.

O sofrimento de Jesus se repete, tão intenso como nos evangelhos bíblicos. Mas o narrador explica a inscrição colocada sobre a cabeça de Jesus como uma artimanha para frustrar os planos de Deus. Jesus pensou que, se morresse como rei dos judeus, Deus não seria glorificado por sua morte, e deste modo pouparia milhões de vidas. Seu último pedido a Pilatos foi o seguinte:

Peço que mandes pôr em cima da minha cabeça um letreiro em que fique dito, para que me conheçam, quem sou e o que sou, Nada mais, Nada mais. Pilatos fez sinal a um secretário, que lhe trouxe o material de escrita, e, por sua própria mão, escreveu Jesus de Nazaré Rei dos Judeus (p. 443).

\footnotetext{
18 Para Borges (2010, p. 51), “Caim é, apesar de carregar o fardo do justiceiro pelas próprias mãos, um exemplo de lucidez no meio da escuridão. Condena os actos de condenação da parte de Deus e julga-o sem o mínimo receio, mas sempre em busca da justiça humana [...]". A ideia de uma pessoa lúcida "em meio à escuridão" é muito apreciada por Saramago.

${ }^{19}$ No Novo Testamento, Judas aceita trinta moedas de prata, mas se arrepende e as devolve antes de enforcar-se (Mt 27 , $1-5)$.
} 
No entanto, a estratégia de Jesus não funciona. E Saramago conclui seu romance parodiando a última cena da vida de Jesus. Nela, ao invés de invocar seu pai, entregando em Suas mãos o seu espírito (Lc 23, 46), ou sofrer porque se sente abandonado (Mt 23, 46; Mc 15, 34), ou morrer com a serenidade de um estoico (Jo 19, 30), Jesus clama aos homens que perdoem a Deus, pois ele é que não sabe o que faz ${ }^{20}$ :

de súbito o céu por cima da sua cabeça se abre de par em par e Deus aparece, vestido como estivera na barca, e a sua voz ressoa por toda a terra, dizendo, Tu és o meu Filho muito amado, em ti pus toda a minha complacência ${ }^{21}$. Então Jesus compreendeu que viera trazido ao engano como se leva o cordeiro ao sacrifício, que a sua vida fora traçada para morrer assim desde o princípio dos princípios, e, subindo-lhe à lembrança o rio de sangue e de sofrimento que do seu lado irá nascer e alagar toda a terra, clamou para o céu aberto onde Deus sorria, Homens, perdoai-lhe, porque ele não sabe o que fez (p. 444).

Em Caim, Saramago parafraseia o quase sacrifício de isaac por seu pai abraão. Este episódio já fora referido no Evangelho para marcar que Deus não sentia culpa pelos inocentes mortos em Belém e para mostrar que em tempos remotos Deus apiedara-se do pai que tinha de matar o filho, enquanto ele não se apiedava do próprio filho que obrigara a morrer na cruz para que ele, o pai, tivesse seu poder ampliado (p. 391). Caim compartilha da estupefação do narrador diante de uma ordem tão absurda que deus dera a abraão, e protesta contra a estupidez do pai, que decide cumpri$1 a^{22}:$

O leitor leu bem, o senhor ordenou a abraão que lhe sacrificasse o próprio filho, com a maior simplicidade o fez, como quem pede um copo de água quando tem sede, o que significa que era costume seu, e muito arraigado. O lógico, o natural, o simplesmente humano seria que abraão tivesse mandado o senhor à merda, mas não foi assim. Na manhã seguinte, o desnaturado pai levantou-se cedo para pôr os arreios no burro, preparou a lenha para o fogo do sacrifício e pôs-se a caminho para o lugar que o senhor lhe indicara, levando consigo dois criados e o seu filho isaac. No terceiro dia da viagem, abraão viu ao longe o lugar referido. Disse então aos criados, Fiquem aqui com o burro que eu vou até lá adiante com o menino, para adorarmos o senhor e depois voltamos para junto de vocês ${ }^{23}$. Quer dizer, além de tão filho da puta como o senhor, abraão era um refinado mentiroso (p. 79).

Caim impede o sacrifício de isaac, e só depois o anjo chega declamando o texto em que pede a abraão que não mate o filho porque o senhor percebeu sua fé. Caim o interrompe, e aí a paráfrase converte-se em ridicularização irônica: caim faz o anjo perceber que se atrasara, e este explica que uma de suas asas teve um problema mecânico durante o voo (p. 80).

\footnotetext{
${ }^{20}$ A última frase parodia uma citação muito famosa dos evangelhos: "Pai, perdoai-os, porque eles não sabem o que fazem", presente em Lc 23, 34 .

${ }^{21}$ Paráfrase de Mt 3, 17; Mt 17, 4; Mc 1, 11; Mc 9, 7; Lc 9, 35; At 1, 17. Nos Evangelhos, Deus pronuncia essa frase no batismo de Jesus por João Batista e num episódio em que Jesus conduz alguns apóstolos, João, Pedro e Tiago, a uma montanha, onde lhe aparecem, antes da voz de Deus, Moisés e Elias.

${ }_{22}$ Peres (s/d, p. 9) explica que "o Deus da nova aliança leva ao cabo o sacrifício de Jesus (e dos homens) enquanto o da velha poupa Isaac após confirmar a fé de Abraão, e por isso a nova religião é mais identificada com a guerra no romance [refere-se ao Evangelho]."

${ }^{23} \mathrm{O}$ episódio do sacrifício de isaac é uma paráfrase de Gn 22, 2-19.
} 
De acordo com Finkelstein \& Silberman (2003, p. 176) “os patriarcas não existiram, nem o Êxodo, nem a conquista de Canaã, nem a monarquia unificada sob a liderança de Davi e de Salomão", de modo que, sob esta perspectiva, o quase sacrifício de Isaac é uma invenção, pois, se Abraão não existiu, tampouco existiu seu filho ${ }^{24}$.

Johnson pensa de modo completamente diferente:

Abrão, descendente em última instância de Noé, migrou de Ur dos caldeus, primeiro para Haram, e depois para vários lugares em Canaã, viajando até o Egito em tempos de fome mas regressando a Canaã e terminando seus dias em Hebron, onde fez a sua primeira compra de terras.

A substância desse relato bíblico é histórica. [...] não há qualquer motivo que nos leve a duvidar que Abraão veio de Ur, como o declara a Bíblia, e isso já nos diz muito sobre ele (1995, p.22).

Quando caim encontra a torre de babel, todos já estão a falar línguas diferentes, sem se entenderem. Deus puniu os homens pelo mesmo motivo que os puniu no jardim do éden: porque não admite que suas criaturas se tornem mais inteligentes e poderosas: "O ciúme é o seu grande defeito, em vez de ficar orgulhoso dos filhos que tem, preferiu dar voz à inveja, está claro que o senhor não suporta ver uma pessoa feliz" (p. 86). Desse modo, "Disse que depois de nos termos posto a fazer a torre ninguém mais nos poderia impedir de fazer o que quiséssemos, por isso confundiu-nos as línguas e a partir daí, como vês, deixámos de entender-nos" (id., ib.).

Segundo Liverani (2008, p. 293), "na Babilônia, havia edifícios desmoronados e imensas ruínas. Entre elas se erguia a 'torre de Babel', ou melhor, erguiam-se várias delas”. Para ele,

No folclore popular, as ruínas (que em si são efeito de uma degradação posterior à edificação) são muitas vezes entendidas ao contrário, como construções incompletas, e portanto desencadeiam a fantasia de imaginar histórias que expliquem como a construção não chega a se completar e fica maldita para sempre. A breve narrativa da torre de Babel (Gn 11, 1-9) insere-se claramente nessa tipologia de histórias etiológicas. [...]

$\mathrm{Na}$ narrativa se inseriu também a experiência de trabalho dos deportados, de origem e línguas diferentes (hebreus, arameus, anatólicos, iranianos), utilizados pelos babilônios como mão-de-obra para as construções, sob vigilantes que davam ordens numa outra língua ainda (id., p. 293-295).

O episódio que mais irritou caim foi o da destruição de sodoma e gomorra. Saramago utiliza um longo trecho do Gênesis para enfatizar a injustiça cometida por deus e o engodo que ele aplica em abraão. Haviam chegado ao céu queixas contra os habitantes de sodoma e gomorra, cujos homens estavam preferindo relacionar-se com outros homens. Deus desceu à terra para tirar a questão a limpo, pois, apesar de sua onisciência, parece que não podia verificar do céu tudo quanto estava acontecendo. Encontra-se com abraão, que o acompanha, e promete-lhe poupar as cidades caso haja inocentes.

Se eu encontrar na cidade de sodoma cinquenta pessoas que estejam inocentes, perdoarei a toda a cidade em atenção a elas. [...] Se lá encontrar quarenta e cinco que estejam inocentes, também não destruo a cidade, [...] Suponhamos agora que existam lá quarenta que estão inocentes, e o senhor respondeu, Por esses quarenta também não destruirei a cidade, E se lá se encontrarem trinta, Por esses trinta não farei mal à cidade, E se forem vinte, insistiu abraão, Não a destruirei por atenção a esses

\footnotetext{
${ }^{24}$ Liverani (2008, p. 309) concorda com Finkelstein \& Silberman, e afirma que os patriarcas são um mito de fundação.
} 
vinte. Então abraão atreveu-se a dizer, Que o meu senhor não se enfade se eu perguntar uma vez mais, Fala, disse o senhor, Suponhamos que existem lá só dez pessoas inocentes, e o senhor respondeu, Também não a destruirei em atenção a essas dez ${ }^{25}$ (p. 93).

No entanto, "O senhor fez então cair enxofre e fogo sobre sodoma e sobre gomorra e a ambas destruiu até aos alicerces, assim como a toda a região com todos os seus habitantes e toda a vegetação" $26 "$ (p. 97). Caim diz ao patriarca: "Penso que havia inocentes em sodoma e nas outras cidades que foram queimadas". Este, contudo, retruca que, "Se os houvesse, o senhor teria cumprido a promessa que me fez de lhes poupar a vida". Mas caim remata a discussão: “As crianças, disse caim, aquelas crianças estavam inocentes, Meu deus, murmurou abraão e a sua voz foi como um gemido, Sim, será o teu deus, mas não foi o delas” (p. 97).

Para Liverani (2008, p. 263), quando a Bíblia conta a história de "Sodoma e Gomorra (destruídas por sua impiedade, salvo a família do inocente Lot); [...] estamos na realidade falando da destruição de Jerusalém e da desertificação de Judá”.

Moisés desceu do monte Sinai e viu que seu povo adorava a imagem de um bezerro, como se de um deus se tratasse. "Eis o que diz o senhor, deus de israel, pegue cada um numa espada, regressem ao acampamento e vão de porta em porta, matando cada um de vocês o irmão, o amigo, o vizinho. E foi assim que morreram cerca de três mil homens ${ }^{27}$ " (p. 101). Na sequência, deus manda que moisés se vingue dos madianitas porque estes tinham atacado os israelitas e os enganado com falsos ídolos: "moisés mandou a cada uma das doze tribos de israel que pusessem mil homens para a guerra e assim reuniu um exército de doze mil soldados que destroçou o dos madianitas, nenhum dos quais escapou com vida ${ }^{28} "$ (p. 104).

Finkestein e Silberman afirmam que os acampamentos e ocupações do monte Sinai e seus arredores, por judeus, na época de Ramsés II e dos seus imediatos predecessores e sucessores não ocorreram, sugerindo que a história de Moisés, suas tábuas da Lei e as carnificinas referidas são apenas invenção, sem fundamento histórico. Segundo os autores (2003, p. 92-94), "Repetidas pesquisas arqueológicas [...] não produziram senão evidências negativas: nem mesmo um único caco ou fragmento antigo".

A conquista de Jericó e a posterior derrota dos cinco reis amorreus é parafraseada por Saramago, mas, a esta última, o autor acrescenta um diálogo entre josué e deus no qual este explica ao guerreiro que não pode fazer o sol parar, como consta na Bíblia, pois não é o sol que gira em torno da Terra, e sim a Terra que gira em torno do sol. Deus acrescenta que, se fizesse parar a Terra, o mundo todo entraria em colapso, pois, ainda que seja deus, não pode subverter as regras do

\footnotetext{
Paráfrase de Gn 18, 23-33.

Paráfrase de Gn 19, 24-25.

Paráfrase de Ex 32, 27-28.

Conforme Nm 25, 17-18.
} 
universo que ele mesmo criou. Saramago mantém o texto no passado, mas situa o discurso no contexto da contemporaneidade, em que o equívoco do autor do texto bíblico é inadmissível porque sabemos mais do que o deus dos judeus, que ignorava as leis de rotação e translação.

A derrubada dos muros que cercavam Jericó ocorre da mesma forma que está narrada na Bíblia $^{29}$. Conforme ordenou o senhor, josué fez seus soldados desfilarem em volta da cidade uma vez por dia, durante seis dias, junto com a arca da aliança, diante da qual andavam sete sacerdotes, "cada um soprando um chofar de chifre de carneiro". No sétimo dia, deus ordenou que dessem sete voltas à cidade, com os sacerdotes tocando os chofares. Disse que,

quando eles emitirem um som mais prolongado, o povo deve gritar com toda a força e então as muralhas da cidade cairão por terra. Contrariando o mais legítimo cepticismo, assim aconteceu. Ao cabo de sete dias desta manobra táctica nunca antes experimentada, as muralhas caíram mesmo e toda a gente entrou correndo na cidade, cada qual pela abertura que tinha na sua frente, e jericó foi conquistada. Destruíram tudo o que havia, matando à espada homens e mulheres, novos e velhos, e também os bois, as ovelhas e os jumentos. [...] Os soldados de josué lançaram fogo à cidade e queimaram tudo o que lá havia, à excepção da prata, do ouro, do bronze e do ferro que, como de costume, foram levados para o tesouro do senhor. Foi então que josué fez a seguinte ameaça, Maldito seja quem tentar reconstruir a cidade de jericó, morra o filho mais velho a quem lhe lançar os alicerces e o mais novo a quem lhe levantar as $\operatorname{portas}^{30}$ (p. 110-111).

Sabendo que um judeu, soldado de josué, não destruíra "coisas que estavam condenadas à destruição", deus deixa seu povo desvalido, e por isso os soldados de josué são obrigados a fugir de uma batalha. Josué lamenta a desonra, e deus explica-lhe que lhes abandonará a menos que josué encontre o traidor que está de posse daquilo que já devia ter destruído, e, depois, queime-o “com tudo que lhe pertença, família e bens" (p. 113-114).

A investigação de josué alcança êxito, e ele encontra o culpado: acan $^{31}$.

Josué tomou então acan com a prata, o manto e a barra de ouro, mais os filhos e filhas, bois, jumentos e ovelhas, a tenda e tudo o que ele tinha, e levou-os até ao vale de acor. Chegados lá, josué disse, Já que foste a nossa desgraça, pois por tua culpa morreram trinta e seis israelitas, que o senhor agora desgrace a ti. Então todas as pessoas o apedrejaram e, em seguida, lançaram-nos ao fogo, a eles e a tudo o que tinham. Puseram depois sobre acan um grande monte de pedras que ainda está lá. [...] Assim se acalmou a ira de deus, mas, antes que o povo se dispersasse, ainda se ouviu a estentória voz a clamar, Ficam avisados, quem mas fizer, paga-mas, eu sou o senhor (p. 114-115).

Na sequência, josué parte para a conquista de Canaã, derrotar os cinco reis amorreus que a dominavam. Este episódio só o narrador presencia, pois caim, que acompanhava o exército, foi embora: "já não suporto ver tantos mortos à minha volta, tanto sangue derramado, tantos choros e tantos gritos" (p. 116). No meio da batalha, josué pede ao senhor que pare o sol para prolongar o dia. Deus explica-lhe que não pode, só o que fará será limpar o céu das nuvens e dar ânimo aos soldados. Antes de partir, avisa a josué: “Não falarás a ninguém sobre o que foi tratado aqui entre nós, a história que virá a ser contada no futuro terá de ser a nossa e não outra, josué pediu ao senhor

\footnotetext{
29 Ver Js 6.

${ }^{30}$ Conforme Js 6, 26.

${ }^{31}$ A narração de Saramago parafraseia Js 7, 24-26.
} 
que detivesse o sol e ele assim fez, nada mais" (p. 119-120). Em seguida, ordena: "vence tu, josué, esses cinco reis amorreus que me desafiam, e canaã será o fruto maduro que em breve te cairá nas mãos, avante, pois, e que nenhum amorreu sobreviva ao gume da espada dos israelitas" (p. 120) ${ }^{32}$.

O episódio da derrubada de Jericó e da conquista de Canaã é mais um que recebe tratamento muito diverso pelos historiadores. Segundo Johnson,

Com a entrada em Canaã e a conquista dessa terra [...] o padrão de acontecimentos históricos começa
a esclarecer-se, na medida em que a evidência arqueológica confirma ou ilumina crescentemente o
relato bíblico. O Livro de Josué, assim chamado por causa do primeiro grande comandante militar
israelita, pode agora ser considerado essencialmente um relato histórico [...].
O primeiro lugar que caiu, depois de cruzado o Jordão, foi Jericó, uma das cidades mais antigas do
mundo. As escavações de Kathleen Kenyon e a datação pelo teste de carbono mostram que ela
remonta ao sétimo milênio a.C ${ }^{33}$. Era cercada por enormes muralhas nas Idades de Bronze Antiga e
Média, e a força de suas defesas produziu uma das passagens mais vívidas na Bíblia. [...] Devido à
erosão, as pesquisas Kenyon não lançaram luz sobre a maneira pela qual as muralhas foram
destruídas; ela pensa que pode ter havido um terremoto, que os israelitas atribuíram à intervenção
divina. [...] Miss Kenyon estabeleceu que a cidade foi certamente queimada naquela época e que, além
disso, não foi reocupada, depois disso, durante um tempo muito longo, o que concorda com a
determinação de Josué de que ninguém a reconstruísse (1995, p. 53-54).

Liverani (2008, p. 343), ao contrário, afirma que “A união entre 'saída' do Egito e 'entrada' em Canaã está notoriamente entre as mais artificiais e complicadas de todo o corpus de tradições que confluíram no Antigo Testamento", e que "A narrativa bíblica da conquista 'fundante' é notoriamente uma construção artificial, com a intenção de enfatizar a unidade de ação de todas as doze tribos" (id., p. 347). Sobre a queda dos muros de Jericó, explica que eles não foram derrubados, pois já estavam em ruínas na época de Josué: “Trata-se, portanto, de uma típica narrativa etiológica, com intenção de explicar como a cidade estava destruída havia tanto tempo" (id., p. 351).

Finkelstein e Silberman, por sua vez, dizem que nem havia muros para serem derrubados. Segundo eles,

as cidades de Canaã não eram fortificadas, e não existiam muralhas que pudessem desmoronar. No caso de Jericó, não havia traços de nenhum povoamento no século XIII a.C. ${ }^{34}$, e o antigo povoado, da Idade do Bronze anterior, datando do século XIV a.C., era pequeno e modesto, quase insignificante, e não fortificado. Também não havia nenhum sinal de destruição. Assim, a famosa cena das forças israelitas marchando ao redor da cidade murada com a Arca da Aliança, provocando o desmoronamento das poderosas muralhas pelo clangor estarrecedor de suas trombetas de guerra, era, para simplificar, uma miragem romântica (2003, p. 119).

\footnotetext{
32 Conforme Js 10.

${ }^{33}$ Esta data refere-se ao início do povoamento de Jericó. A narrativa de Josué é situada no décimo terceiro século a.C. As Idades de Bronze Antiga e Média que são citadas na frase seguinte são datadas, respectivamente, entre 3500 a.C. a 2200 a.C., e 2000 a.C. a 1550 a.C., ou seja, milênios depois. Segundo a Bíblia, porém, a terra teria muito menos do que sete milênios na época em que viveu Josué.

${ }^{34}$ Esta data é histórica e teologicamente coerente. Ela se refere não ao início do povoamento, mas ao suposto momento em que a cidade fora destruída pelas tropas de Josué.
} 
A aposta de deus e do diabo contra job ${ }^{35}$ constitui-se de uma paráfrase de Saramago que aproxima a figura de deus e do demônio, quase a ponto de, como no Evangelho, situá-los como irmãos gêmeos.

Caim trabalhava como empregado de job, um homem rico e muito temente a deus. Este, provocado pelo demônio, concede ao diabo "carta de plenos poderes" para matar os filhos e filhas de job, seus rebanhos, escravos, e atacar-lhe com doenças. O narrador questiona estes poderes:

antes de prosseguir sejam-nos permitidas umas quantas observações. A primeira para manifestar estranheza pelo facto de satã poder dispor a seu bel-prazer dos sabeus e dos caldeus para serviço dos seus interesses particulares, a segunda para expressar uma estranheza ainda maior por satã haver sido autorizado a servir-se de um fenómeno natural, como foi o caso do furacão, e, pior ainda, e isso, sim, inexplicável, por utilizar o próprio fogo de deus para queimar as ovelhas e os escravos que as guardavam. Portanto, ou satã pode muito mais do que pensávamos, ou estamos perante uma gravíssima situação de cumplicidade tácita, pelo menos tácita, entre o lado maligno e o lado benigno do mundo (p. 138).

Caim conversa com um anjo e pergunta-lhe se deus apostou porque tinha a certeza de que ia ganhar. O anjo responde-lhe que, "De certo modo, sim, Portanto, tudo ficou como estava, neste momento o senhor não sabe mais de job do que aquilo que sabia antes, Assim é” (p. 141). Caim protesta, inconformado com todas as mortes decorrentes de uma aposta inútil.

Para arrematar, Deus ainda realiza uma última vingança contra as criaturas que criara. Puniu-as porque ficariam mais espertas após comerem do fruto proibido, o da árvore do conhecimento do bem e do mal; puniu-as porque construíam uma torre gigantesca que os faria sentir-se poderosos; agora, vai puni-las porque são más, isto é, porque continuam se tornando cada vez mais parecidas com ele:

vou lançar um dilúvio de água que, ao inundar tudo, eliminará debaixo do céu todos os seres vivos que existem no mundo, tudo quanto há na terra vai morrer, mas contigo, noé, fiz um pacto de aliança, no momento próprio estarás na arca com os teus filhos, a tua mulher e as mulheres dos teus filhos, e de todas as espécies de seres vivos levarás para a arca dois exemplares, macho e fêmea, para poderem viver juntamente contigo (p. 151) ${ }^{36}$

Caim explica a deus que a arca não flutuará, pois sua construção não respeita o princípio de Arquimedes, segundo o qual

um barco deve ser construído junto à água, não num vale rodeado de montanhas, a uma distância enorme do mar, quando está terminado empurra-se para a água e é o próprio mar, ou o rio, se for esse o caso, que se encarregam de o levantar, talvez não saibas ${ }^{37}$ que os barcos flutuam porque todo o corpo submergido num fluido experimenta um impulso vertical e para cima igual ao peso do volume do fluido desalojado (p. 152).

A paródia denuncia a ignorância do autor desta história do Gênesis. Caim só conhece o princípio de Arquimedes porque é um personagem da paródia, que, por ser paródico, não tem

35 O Livro de Jó é todo ele dedicado a essa aposta e a suas consequências.

36 Gn 6, 17-21.

37 Deus, mais uma vez, tem sua onisciência contestada. 
necessidade de ser verossímil ${ }^{38}$. Apesar de a matemática desmentir a possibilidade da arca, Johnson (1995, p. 21) mantém-se fiel à sua fé39 e afirma que Noé é “o primeiro homem real na história judaica”, e que o Dilúvio é “o primeiro acontecimento histórico para o qual existe confirmação nãobíblica". Ele explica essa confirmação da seguinte maneira:

\begin{abstract}
Enquanto investigava os níveis arqueológicos mais antigos em Ur, Woolley fez esforços prolongados para desenterrar evidência física de uma inundação dramática. Encontrou um depósito aluvial de 8 pés, a que ele atribuiu a data de entre 4000 a 3500a.C. [...] Então, em 1965, o Museu britânico fez uma outra descoberta em seus depósitos: duas tabuinhas, que se referem ao Dilúvio, escritas na cidade babilônica de Sippar, no reino do Rei Amisaduca, 1646-1626 a.C.

A importância dessa última descoberta consiste em que nos permite focalizar a própria figura de Noé, pois relata como o deus, tendo criado a humanidade, se arrependeu e decidiu afogá-la com uma inundação; mas Enk, o deus da água, revelou o plano catastrófico a um certo sacerdote chamado Ziusudra, que construiu um barco e assim sobreviveu. [...] A figura salvadora de Ziusudra, apresentada na Bíblia como Noé, proporciona assim a primeira confirmação independente da existência real de uma personagem bíblica (id., p. 20-21)
\end{abstract}

Liverani (2008, p. 291) aproveita as semelhanças entre as histórias para, ao contrário de Johnson, explicar que as histórias contidas nas tabuinhas ${ }^{40}$ demonstram que a narrativa bíblica é “um caso evidente de derivação literária”. Para Liverani,

\begin{abstract}
Muitas e muito precisas são as concordâncias da narrativa bíblica com as versões babilônias do mito conservadas no poema de Atram-khasis e no de Gilgamesh. O próprio encalhe da arca "sobre os montes de Uratu" (Gn 8,4) demonstra não somente a origem babilônia da narrativa bíblica, mas também sua transmissão no período neobabilônio.

De resto, a própria idéia de um crescimento das águas a ponto de submergir todas as terras não pode condizer com a configuração física da região palestina, feita de colinas e montanhas, mas se adapta muito bem ao "mapa mental" babilônio, feito de um amplo aluvião (o vale do Tigre e do Eufrates) circundado por montanhas: um mundo, portanto, em forma de tigela com as bordas realçadas para contenção das águas. Na Babilônia, a experiência das inundações era recorrente e até estruturalmente constitutiva dos ritmos das estações (id., p. 291).
\end{abstract}

Com base nestas considerações, Liverani (id., p. 292) conclui que os registros arqueológicos “testemunham não mais o dilúvio arquetípico, mas as recorrentes inundações 'históricas"”.

\title{
4 Considerações finais
}

Saramago refere-se em vários romances aos limites da ciência, que se mostra incapaz de responder a muitas das perguntas que fazemos a ela, bem como recria eventos históricos a seu modo, questionando a historiografia, pois esta, como produto humano, é limitada. As divergências entre os estudiosos, historiadores e arqueólogos que analisam a Bíblia e confrontam seus textos com os vestígios do passado, também nos fazem perceber que a polêmica envolvendo a Bíblia não se situa apenas no plano da religião e da literatura, mas também se inscreve no discurso científico.

\footnotetext{
${ }^{38}$ Caim não poderia conhecer Arquimedes, nascido muito depois da época em que o próprio romance situa o dilúvio, além de que, como agricultor, ele dificilmente entenderia da construção de gigantescas arcas.

${ }^{39}$ O primeiro parágrafo do livro História do judaísmo explicita a perspectiva do autor, confessadamente cristão: "Determinei-me, portanto, desde que sobreviesse oportunidade, a escrever a respeito do povo que dera origem à minha fé" (p. 13).

${ }^{40} \mathrm{~A}$ referência à data em que foram encontradas sugere que as tabuinhas citadas por Johnson são diferentes das referidas por Liverani.
} 
Alguns críticos, religiosos e leitores afirmam que no Evangelho e em Caim Saramago deturpa os textos bíblicos. Porém, o que essas narrativas têm de mais recorrente são citações ipsis litteris e paráfrases do Antigo e do Novo Testamentos. Saramago utiliza as citações e as paráfrases para apresentar as narrativas bíblicas novamente ao público, de modo a revelar o que considera iniquidades de Deus.

Nas paródias de Saramago, o estranhamento que a imagem de Deus/deus produz não é resultado de uma heresia do autor. Decorre, ao contrário, do fato de ser um personagem criado em conformidade com o personagem homônimo da Bíblia, imitado por Saramago de modo literal e sem eufemismos. Nos dois romances, os narradores assumem a perspectiva dos protagonistas, Jesus e caim, os quais questionam Deus/deus e manifestam a visão crítica pessoal de Saramago contra o discurso da Bíblia, que, segundo ele, é "um manual de maus costumes, um catálogo de crueldade e do pior da natureza humana" 41 .

\section{Referências}

BORGES, António José. Ainda a recorrência a um tema religioso/social em Caim de José Saramago. In: Revista Navegações, v. 3, n. 1, p. 48-52, jan./jun. 2010, p. 48-52.

CUNHA, Paulo Ferreira da. Liberdade \& Hermenêutica - Antropologia Teológica, Exegese e Liberdade Religiosa a propósito de "Caim", de José Saramago. In: International Studies on Law and Education 6, jul-dez 2010, CEMOrOc-Feusp / IJI-Univ. do Porto

DIÓGENES, Nivaldo Medeiros. O limiar da humanização no romance Caim de José Saramago. In: Revista Desassossego 6, dez. 2011, p. 59-72.

FELDMAN, Sérgio Alberto. A mulher na religião judaica (período bíblico: primeiro e segundo Templos). In: MÉTIS: história \& cultura - v. 5, n. 10, p. 251-272, jul./dez. 2006, p. 251-272.

FERRAZ, Salma. O diabo pede perdão: a redenção do diabo por Saramago. Revista Labirintos. Feira de Santana: UEFS. Disponível em:<http://www.uefs.br/nep/labirintos/edicoes/02_2008/12_artigo_salma_ferraz.pdf>.

O quinto evangelista: o (des)evangelho segundo José Saramago. Brasília: Editora Universidade de Brasília, 1998.

FINKELSTEIN, Israel; SILBERMAN, Neil Asher. A Bíblia não tinha razão. Tradução de Tuca Magalhães. SP: A Girafa, 2003. Título original: The Bible unearthed: archeology's new vision of ancien Israel and the origin of its sacred texts.

HUTCHEON, Linda. Uma teoria da paródia: ensinamentos das formas de arte do século XX. Trad. Teresa Louro Pérez. Lisboa: Edições 70, 1989.

. Poética do pós-modernismo: história, teoria, ficção. Tradução de Ricardo Cruz. Rio de Janeiro: Imago, 1991.

JOHNSON, Paul. História do judaísmo. Tradução de Henrique Mesquita e Jacob Volfzon Filho. Rio de Janeiro: Imago, 1995.

\footnotetext{
${ }^{41}$ Fala disponível em: http://www.publico.pt/cultura/noticia/biblia-e-manual-de-maus-costumes-diz-o-escritor-josesaramago-1405681
} 
KOCHMANN, Sandra . O Lugar da Mulher no Judaísmo. In: Revista de Estudos da Religião $N^{o} 2$, 2005 , p. 35-45.

LEAL, Eliane Alves. "Caim" de Saramago: a desconstrução do mito bíblico judaico-cristão a partir da paródia. In: Anais do SILEL. Volume 2, Número 2. Uberlândia: EDUFU, 2011.

LIMA, Rita de Lourdes de. O imaginário judaico-cristão e a submissão das mulheres. In: Fazendo Gênero 9: Diásporas, Diversidades, Deslocamentos. 23 a 26 de agosto de 2010.

LIVERANI, Mario. Para além da Bíblia: História antiga de Israel. Tradução de Orlando Soares Moreira. SP: Paulus \& Loyola, 2008.

LOPES, Marcos Aparecido. Deus e o Diabo na hermenêutica de Saramago. In: Remate de Males, jul./dez. 2009, p. 319-332.

MILES, Jack. Deus: uma biografia. Tradução de José Rubens Siqueira. São Paulo: Companhia das Letras, 2009.

NONNEMACHER, Dalila Batista. José Saramago. In: COSTA, Lígia Militz da et al. L. F. Veríssimo, J. Saramago e G. G. Márquez: a paródia na ficção contemporânea. Cruz Alta: Unicruz/Pallotti, 2004.

OLIVEIRA, Yani Rebouças de. As imagens femininas da tradição cristã nO evangelho segundo Jesus Cristo, de José Saramago. In: Anais do SILEL. Volume 1. Uberlândia: EDUFU, 2009.

PERES, Mônica. Autoria, alteridade e autoridade no Evangelho de Saramago. Revista Desassossego. São Paulo: USP. Disponível <http://www.revistas.usp.br/desassossego/article/view/47370/51107>.

SANT'ANNA, Afonso Romano de. Paródia, paráfrase e cia. São Paulo: Ática, 2003.

SANTOS, Ana Pinheiro dos. Maria Madalena no cristianismo primitivo: Desafio para reflexões cristãs modernas. In: Revista Caminhando v . 12 , n . 20 , p . 29 - 42 , jul - dez 2007.

SARAMAGO, José. Caim. São Paulo: Companhia das Letras, 2009.

O evangelho segundo Jesus Cristo. São Paulo: Companhia das Letras, 2011.

SOUZA, Ronaldo Ventura. A crise da autoridade em O evangelho segundo Jesus Cristo. In: Revista Querubim, 2010 Ano 06 n $^{\circ}$ 10, p. 105-113.

. Os dois lados da mesma moeda: Deus e o Diabo em $\mathrm{O}$ evangelho segundo Jesus Cristo. Revista Desassossego. São Paulo: USP. Disponível em: <http://www.revistas.usp.br/desassossego/article/viewFile/47417/51148>.

TENÓRIO, Waldecy. A paixão religiosa de Saramago: leitura de O Evangelho Segundo Jesus Cristo, de José Saramago. In: Revista Lusófona de Ciência das Religiões, Ano VI, n.11, 2007, pp. 295-305. 